\title{
Fanconi Anemia Core Complex-Associated Protein 100
}

National Cancer Institute

\section{Source}

National Cancer Institute. Fanconi Anemia Core Complex-Associated Protein 100. NCI

Thesaurus. Code C92481.

Fanconi anemia core complex-associated protein 100 (881 aa, 93 kDa) is encoded by the human FAAP100 gene. This protein is involved in the Fanconi anemia complex response to DNA damage. 